\title{
Memory Generation and Re-Activation in Food Allergy
}

\author{
Joshua FE Koenig (D) \\ Kelly Bruton' \\ Allyssa Phelps' \\ Emily Grydziuszko' \\ Rodrigo Jiménez-Saiz $\mathbb{D}^{1-4}$ \\ Manel Jordana' \\ 'McMaster Immunology Research \\ Centre, Department of Medicine, Faculty \\ of Health Sciences, McMaster University, \\ Hamilton, Ontario, Canada; ${ }^{2}$ Department \\ of Immunology, Instituto de Investigación \\ Sanitaria Hospital Universitario de la \\ Princesa (IIS-IP), Madrid, Spain; \\ ${ }^{3}$ Department of Immunology and \\ Oncology, Centro Nacional de \\ Biotecnología (CNB)-CSIC, Madrid, Spain; \\ ${ }^{4}$ Faculty of Experimental Sciences, \\ Universidad Francisco de Vitoria (UFV), \\ Madrid, Spain
}

\begin{abstract}
Recent evidence has highlighted the critical role of memory cells in maintaining lifelong food allergies, thereby identifying these cells as therapeutic targets. $\operatorname{IgG}^{+}$memory $B$ cells replenish pools of IgE-secreting cells upon allergen exposure, which contract thereafter due to the short lifespan of tightly regulated IgE-expressing cells. Advances in the detection and highly dimensional analysis of allergen-specific B and $\mathrm{T}$ cells from allergic patients have provided insight on their phenotype and function. The newly identified Th2A and Tfh13 populations represent a leap in our understanding of allergen-specific $\mathrm{T}$ cell phenotypes, although how these populations contribute to $\operatorname{IgE}$ memory responses remains poorly understood. Within, we discuss the mechanisms by which memory B and T cells are activated, integrating knowledge from human systems and fundamental research. We then focus on memory reactivation, specifically, on the pathways of secondary IgE responses. Throughout, we identify areas of future research which will help identify immunotargets for a transformative therapy for food allergy.
\end{abstract}

Keywords: food allergy, IgE, memory responses, anaphylaxis, B cells, T cells

\section{Introduction}

"They had no fear for themselves for the same man was never attacked twice-never at least fatally".

This quote from Thucydides (460-400 BC) in "The History of the Peloponnesian War" intimates the critical importance of immune memory for survival. ${ }^{1}$ The 20th century witnessed an explosion of knowledge on immune memory against bacteria and viruses, a program referred to as "type 1 immunity", which is generically mediated by $\mathrm{CD}^{+}$Th1 cells and IgG antibodies. By comparison, our understanding of protective memory against helminths, poisons, and toxins-the "type 2 immunity" which is mediated by $\mathrm{CD}^{+} \mathrm{Th} 2$ cells and IgE-has lagged behind. These protective mechanisms can be misdirected toward food antigens, causing potentially lethal reactions. What survival advantage might be conferred by a pernicious immune reaction against largely innocuous foods? In this regard, it has been recently speculated that food allergy, with the attendant imprinting of memory, might be an aberration of homeostatic immune responses whose main purpose is food quality control. ${ }^{2,3}$

$\mathrm{IgE}$ is the principal effector molecule in food-induced type 2 responses. Allergen-specific IgE is bound to tissue-resident mast cells and circulating basophils through its high-affinity receptor, FceRI. Upon re-exposure, the allergen crosslinks surface-bound IgE and triggers mast cell and basophil degranulation, which
Correspondence: Joshua FE Koenig McMaster Immunology Research Centre, Department of Medicine, Faculty of Health Sciences, McMaster University, I 280 Main Street West, Hamilton, ON L8S 4L8, Canada

Email koenigjf@mcmaster.ca 
causes acute allergic reactions including anaphylaxis. Intriguingly, some food allergies such as those to peanut $(\mathrm{PN})$, tree nuts, fish and shellfish are highly associated with anaphylaxis and are lifelong in about $80 \%$ of patients. ${ }^{4}$ This observation spearheaded intense research over the last 10 years to uncover the immunological basis of persistent allergy. ${ }^{5}$

\section{Memory B Cells Maintain Lifelong Food Allergies}

Persistent humoral immunity induced through vaccination has generally been attributed to long-lived plasma cells (PCs). ${ }^{6}$ This notion has been extrapolated to food allergy, ${ }^{7,8}$ but evidence from both mice and humans has disputed this proposition. ${ }^{9}$ For example, in humans allergic to a common fish parasite, Anisakis spp., strict avoidance of fish consumption for at least 10 months caused a decline from $>100 \mathrm{kU} / \mathrm{L}$ to $<3 \mathrm{kU} / \mathrm{L}$ in allergen-specific IgE titers, which relapsed upon fish reintroduction. ${ }^{10}$ Further, it has been recently reported that levels of $\operatorname{IgE}$ to galactose- $\alpha$ 1,3-galactose decline over time in patients who avoid tick bites. ${ }^{11}$ Along these lines, allergen-specific IgE titers and $\mathrm{IgE}^{+} \mathrm{PCs}$ became undetectable at 6 months postsensitization in PN-allergic mice. ${ }^{12}$ In the absence of $\operatorname{IgE}$ production, IgE that remained bound to the surface of mast cells was capable of inducing anaphylaxis for an additional 100 days. However, the capacity to regenerate IgE following subsequent non-sensitizing allergen exposures persisted for at least 15 months. ${ }^{12}$ Given that long-lived PCs are terminally differentiated, non-proliferative cells, these findings argue that memory $B$ cells (MBCs) play a significant role in facilitating $\operatorname{IgE}$ regeneration and persistent allergy. ${ }^{9}$ It is likely that accidental exposures to food allergens drive memory responses that regenerate IgE-secreting cells, thereby maintaining titers of foodspecific IgE. As an alternate hypothesis, allergen-specific MBCs may proliferate homeostatically in response to infections or other inflammatory stimuli and differentiate into antibody-secreting cells. This has been previously observed in the context of vaccination and $\mathrm{IgG}$ responses. ${ }^{13}$ Although it has not been extensively studied in food allergy, in mice co-sensitized to PN and ovalbumin (OVA), sub-clinical exposures to $\mathrm{PN}$ alone led to the generation of both PN-specific and OVA-specific germinal centre (GC) B-cells. ${ }^{14}$

One recent publication proposed that mice chronically exposed to house dust mite generate long-lived IgE- secreting cells which home to the bone marrow and maintain titers of allergen-specific $\operatorname{IgE}^{15}$ In the same study, $\mathrm{IgE}^{+}$PCs were detected in the bone marrow of cat allergic patients, but the longevity of these cells is not known. In patients avoiding food allergens, exposures are thought to be rare and therefore do not likely provide the chronic stimulus required for these observations. Additional research is required to understand the importance of this axis in food allergy.

The existence and functional relevance of $\operatorname{IgE}^{+} \mathrm{MBCs}$ in humans has been contentious. Current evidence shows that these cells are extremely rare or non-existent ${ }^{16}$ and therefore indicates that non-IgE $\mathrm{E}^{+} \mathrm{MBCs}$ hold IgE memory. Nearest neighbor analyses of human peripheral blood mononuclear cells (PBMCs) IGH repertoires identified $\mathrm{IgG}^{+}{ }^{+} \mathrm{B}$ cells as the primary intermediate of IgE-expressing cells in the circulation. ${ }^{17}$ This is consistent with mouse models where $\operatorname{IgG1}^{+}$MBCs facilitated secondary IgE responses. ${ }^{12,14,18,19}$ Collectively, this research has advanced the notion that longlived $\mathrm{IgG1} 1^{+}$MBCs are the main reservoir of IgE-secreting cells and, therefore, the foundation of allergy persistence. $\mathrm{CD}^{+} \mathrm{T}$ cells and IL-4 receptor signaling are critical for MBC reactivation and IgE class-switch recombination (CSR), thereby identifying this axis as an alluring therapeutic target in food allergy. ${ }^{12,20}$ Presumably, memory $\mathrm{CD}^{+}$T cells provide the IL-4/IL-13 signaling necessary for IgE CSR, but the intricate details of the cellular interactions that occur during a recall response remain poorly understood. It is through deciphering this interplay that novel therapeutic targets in food allergy will be identified.

\section{Phenotype of Allergen-Specific Memory B Cells}

Understanding persistent food allergy requires a precise definition of the phenotype and function of allergenspecific memory $\mathrm{B}$ and $\mathrm{T}$ cells. A pivotal limitation is the rarity and technical difficulty of identifying and isolating these cells in humans. For instance, only $\sim 9$ to 100 allergen-specific $\mathrm{CD}^{+} \mathrm{T}$ cells are detected per million $\mathrm{CD}^{+} \mathrm{T}$ cells in PBMCs of allergic patients; similarly, allergen-specific B cells account for $\sim 200$ cells per million B cells. ${ }^{2-24}$ While studies in PBMCs are lowly invasive, they may not be representative of allergen-specific memory cells in mucosal tissues and in secondary lymphoid organs (SLOs). Still, research over the last decade has advanced our understanding of the memory cells that hold IgE responses. 
As abovementioned, $\mathrm{IgG1}^{+} \mathrm{MBCs}$ are thought to be the sole reservoir of IgE-producing cells in mice. In humans, cross-sectional studies using high-throughput sequencing of the immunoglobulin repertoire from allergic and healthy patients have revealed that all upstream isotypes (IgM, IgD, IgG3, IgG1, IgA1, IgG2, IgG4) are clonally related to IgE. ${ }^{18,25} \operatorname{IgG} 1$ and $\operatorname{IgA} 1$ are the most common IgE-related isotypes in the PBMCs and in the gastrointestinal tract, respectively. It is unclear whether these represent clonal families from a primary or secondary response, but given the high-rate of accidental reexposures in $\mathrm{PN}$-allergic patients, it could be inferred that isotypes other than IgG1 hold IgE memory.

Reservoirs other than $\operatorname{IgG} 1^{+}$MBCs have not been thoroughly studied, but some insight has been attained about MBC phenotypes in IgE reactivation. In mice, a population of mature $\mathrm{CD} 80^{+} \mathrm{CD} 73^{+} \mathrm{PDL} 2^{+} \mathrm{IgG} 1^{+}$MBCs yields the majority of secondary IgE-secreting cells, especially those with high affinity for allergen. ${ }^{19}$ Less mature MBC populations $\left(\mathrm{CD} 80^{+/-} \mathrm{CD} 73^{-}\right)$yield low affinity $\mathrm{IgE}$ or re-enter the $\mathrm{GC}$ to affinity mature, but ultimately were found to contribute sparingly to secondary $\operatorname{IgE}$ production. ${ }^{19}$ In humans, MBC phenotypes are less clear. Classically, the MBC population has been defined by the surface expression of $\mathrm{CD} 27$, which has been proven ineffective to encompass all MBC populations. ${ }^{26}$ In this regard, Glass et al. performed a highly multiplexed singlecell screen of PBMCs, bone marrow, lymph nodes and tonsils from healthy donors. ${ }^{27}$ They identified 6 subsets of MBCs, some of them CD27 $7^{-}$CD45RB was shown to be useful for $\mathrm{MBC}$ identification and, its expression, in combination with that of $\mathrm{CD} 27$, correlated better with the degree of somatic hypermutation than CD27 alone. Interestingly, segregating human MBCs by their phenotype informed of function better than their isotype. This questions if the isotype is the ultimate determinant of memory IgE responses. ${ }^{27}$ The mechanisms that direct MBCs towards $\mathrm{IgE}^{+}$PCs must be investigated at the allergen-specific level to best target and reprogram secondary responses in food-allergic patients. ${ }^{9}$

Human allergen-specific B cells have been detected using fluorescently-labeled allergen monomers or multimers. For example, in PN allergy most studies detect Ara h 1- and Ara h 2-specific cells as these are the dominant allergens in $80-95 \%$ of PN-allergic patients in North America, ${ }^{28}$ and Ara $\mathrm{h} 2$ has been reported the immunodominant $\mathrm{PN}$ allergen in the UK. ${ }^{29}$ PN-specific B cells express somatically hypermutated B-cell receptors (BCRs) and form detectable clonal lineages including IgE-expressing cells. ${ }^{25,30-32}$ Multiple VDJ genes conform PN-binding paratopes, indicative of polyclonal B-cell responses. However, there is convergence of PNspecific sequences among unrelated individuals. This suggests bias in the B-cell repertoire towards PN epitopes that may be immunodominant, especially among allergic individuals. $^{24,30,31,33}$ Consistent with observations in mice, circulating IgE-expressing cells detected in food-allergic patients were primarily plasmablasts while IgE-expressing MBCs were rare or absent. ${ }^{17,31}$ Additional studies could investigate the phenotype of allergen-specific MBCs in situations where memory is reactivated, such as during allergen immunotherapy (AIT) or surrounding oral food challenges. ${ }^{24}$

\section{Phenotype of Allergen-Specific Memory T Cells}

The direct identification of allergen-specific $\mathrm{CD} 4{ }^{+} \mathrm{T}$ cells is technically challenging because it requires the use of peptide-loaded MHC-II (in mice) or HLA (in humans). ${ }^{23,34-36}$ Alternatively, allergen-specific $\mathrm{CD} 4^{+}$ $\mathrm{T}$ cells can be identified based on CD154 upregulation when activated in vitro with whole allergen or allergenderived peptides. ${ }^{37,38}$ This method is simpler and is not limited by HLA haplotype. On the other hand, the stimulation could impact gene expression and CD154 may be non-specifically upregulated via bystander activation. ${ }^{39,40}$ $\mathrm{CD} 154^{+}$cells have been used in downstream applications like single-cell RNA sequencing (sc-RNAseq) to explore preferential phenotypes among subsets of expanded clonotypes, including Th2 states associated with food allergy in PN-allergic patients. ${ }^{41}$

Allergen-specific $\mathrm{CD}^{+} \mathrm{T}$ cells from $\mathrm{PN}$-allergic individuals often exhibit a terminally-differentiated or mature phenotype $\left(\mathrm{CD} 45 \mathrm{RO}^{+} \mathrm{CD} 27^{\text {low/- }}\right)$ associated with poor proliferation upon restimulation and potent cytokine expression. ${ }^{42-44}$ They also express the Th2-related markers CRTH2, CD200R, and CCR4. Numerous studies have identified subpopulations of Th2 cells which potently secrete Th2 cytokines. ${ }^{43,45-47}$ A comprehensive evaluation across allergic diseases defined a "Th2A" population, present only in allergic individuals, which upregulates CD161, CRTH2, CD49d and down-regulates CD45RB and $\mathrm{CD} 27 .{ }^{43}$ The frequency of Th2A cells increases upon allergen exposure but, provided that these mature cells have a reduced proliferative capacity, this potentially argues that a precursor memory population seeds additional Th2A cells upon recall. 
Th2A cells decrease but do not vanish following desensitization via oral AIT, and it is unclear whether the suppression of these cells directly causes desensitization. ${ }^{43}$ Likewise, while anti-IL4R $\alpha$ (dupilumab) treatment prevented IgE generation in PN-stimulated PBMC cultures, Th2A cells persisted as demonstrated by sc-RNAseq. ${ }^{21}$ In addition, Th2A cells have been detected by sc-RNAseq in the skin of dupilumab-treated atopic dermatitis patients for up to 1 year after clinical remission. ${ }^{48}$ Th2A cells are likely a heterogeneous population because of the variety of cytokine profiles they are able to secrete. Other complex phenotypes such as Th2-polarized $\mathrm{T}$ regulatory (Treg) cells and IL-17-secreting Th2 cells have been reported in various allergic contexts. It is unclear how these subsets relate to each other and whether they are a hermetic or plastic phenotype. ${ }^{49,50}$

Th2 cells are important players in food allergy, but it remains unclear how they mechanistically contribute to different aspects of allergic pathology. Th2 cells contribute to late phase allergic inflammation, which presumably participates in the development and exacerbation of eosinophilic esophagitis. ${ }^{51}$ However, their precise role in IgE regeneration is controversial. Recent evidence in mouse models suggest that the critical source of IL-4 in primary IgE induction is derived from $\mathrm{T}$ follicular helper (Tfh) cells, not $\mathrm{Th} 2$ cells. ${ }^{52,53}$ Moreover, a subpopulation of IL-13-secreting Tfh cells (Tfh13) that regulates high-affinity IgE production has been identified in mice and allergic patients. ${ }^{54}$ Genetic deletion of Tfh 13 cells did not abrogate IgE production, suggesting that Th2-biased Tfh (Tfh2) cells may be sufficient for low affinity IgE production. How Tfh $2 / \mathrm{Tfh} 13$ cells fit among the heterogeneous $\mathrm{Th} 2$ cells described in allergic patients and the role of Th2 cells in IgE production has not been definitively demonstrated in humans. ${ }^{55}$

\section{Generation of Allergen-Specific Memory T Cells}

Th2 cells were long thought to be the primary IgE driver in food allergy. Consequently, significant research sought to elucidate $\mathrm{Th} 2$ polarization. Naive $\mathrm{CD} 4^{+} \mathrm{T}$ cells in the draining lymph nodes interact with migratory dendritic cells (DCs), which present food allergens that have been captured in the mucosa or the skin. ${ }^{56,57}$ Environmental cues (e.g. IL-33, uric acid crystals, eosinophil peroxidase, etc.) during allergen capture, ${ }^{58}$ or innate-stimulatory properties of given allergens, ${ }^{59}$ cause DC activation (CD80, CD86, CD40), IL12 downregulation, and expression of $\mathrm{OX} 40 \mathrm{~L}$, which ligates
OX40 on T cells. These interactions induce GATA-3 expression, Th2 polarization, and IL-4 production in cognate $\mathrm{CD} 4^{+}$ T cells (Figure 1). ${ }^{5,58}$ Signals exchanged during the DC-T cell synapse (IL-2, IL-7, OX40 signalling, T-cell receptor (TCR) avidity, and the duration of the TCR-MHC interaction, etc.) influence memory Th2 cell survival. ${ }^{5,60-62}$ Ligation of TCRs by MHC increases responsiveness to IL-2, which promotes induction and maintenance of IL-4R $\alpha$ expression. ${ }^{63,64}$ This, in conjunction with OX40/OX40L interactions, promotes robust clonal expansion of Th2 cells and empowers survival. ${ }^{63,64}$ Additionally, T-cell clones with high avidity TCRs outcompete low-avidity clones for MHC interaction, resulting in heightened clonal expansion and a survival advantage. ${ }^{44,63} \mathrm{In}$ sum, signals experienced by naive $\mathrm{CD} 4^{+} \mathrm{T}$ cells during their initial activation influence memory fate decisions, but decisive requirements have yet to be elucidated.

The ontogeny of newly identified subsets such as Th2A cells and how they are selected into the memory pool is unknown. It is plausible that conventional Th2 cells are the precursors of the more highly differentiated Th2A cells. Th2 cells tend to produce relatively fewer cytokines, and IL-5 is mainly produced by highly differentiated Th2 cells. ${ }^{43,65}$ Th2A cells may gain their capacity to produce IL-5 and/or IL-9, in addition to IL-4 and IL-13, as they mature past the conventional Th2 phenotype. ${ }^{43}$ Alternatively, the observation that Th2A cells exist across numerous allergic diseases, and persist despite therapeutic intervention, may suggest that they arise from a unique differentiation pathway. ${ }^{43,48}$

Tfh cells were originally considered a part of the Th2 program according to their shared expression of IL-4. ${ }^{66}$ While the physiological relevance of Th2 cells in driving food allergy remains contentious, Tfh cells have been reported critical for IgE production. ${ }^{67,68} \mathrm{Tfh}$ cell differentiation is initiated through interactions with DCs (IL-2, IL-6, ICOS, etc.) in the T-cell zone but, in contrast to Th2 cell differentiation, low IL-2R $\alpha$ signalling and robust ICOS co-stimulation results in Tfh commitment (Figure 1). Activated pre-GC Tfh cells upregulate Bcl6, effector cytokines (IL-21, IL-4), costimulatory ligands (ICOSL), and chemokine receptors to migrate to the T-B border of the SLOs $\left(\mathrm{CXCR} 5^{\mathrm{hi}}\right.$, PD- $1^{\mathrm{hi}}$, $\left.\mathrm{CCR} 77^{\mathrm{lo}}\right) .{ }^{69-72} \mathrm{Tfh}$ cell maturation evolves via interactions with antigen-primed $\mathrm{B}$ cells at the T-B border. $^{72,73}$ Here, ICOS/ICOSL and CD40/CD40L costimulation and Tfhderived IL-21 retain the Tfh phenotype and allow these cells to penetrate the B-cell follicle to join or initiate GCs. ${ }^{52,71}$ It is within the GC that the newly identified Tfh 13 population has been reported, but it is unknown at what point these cells 


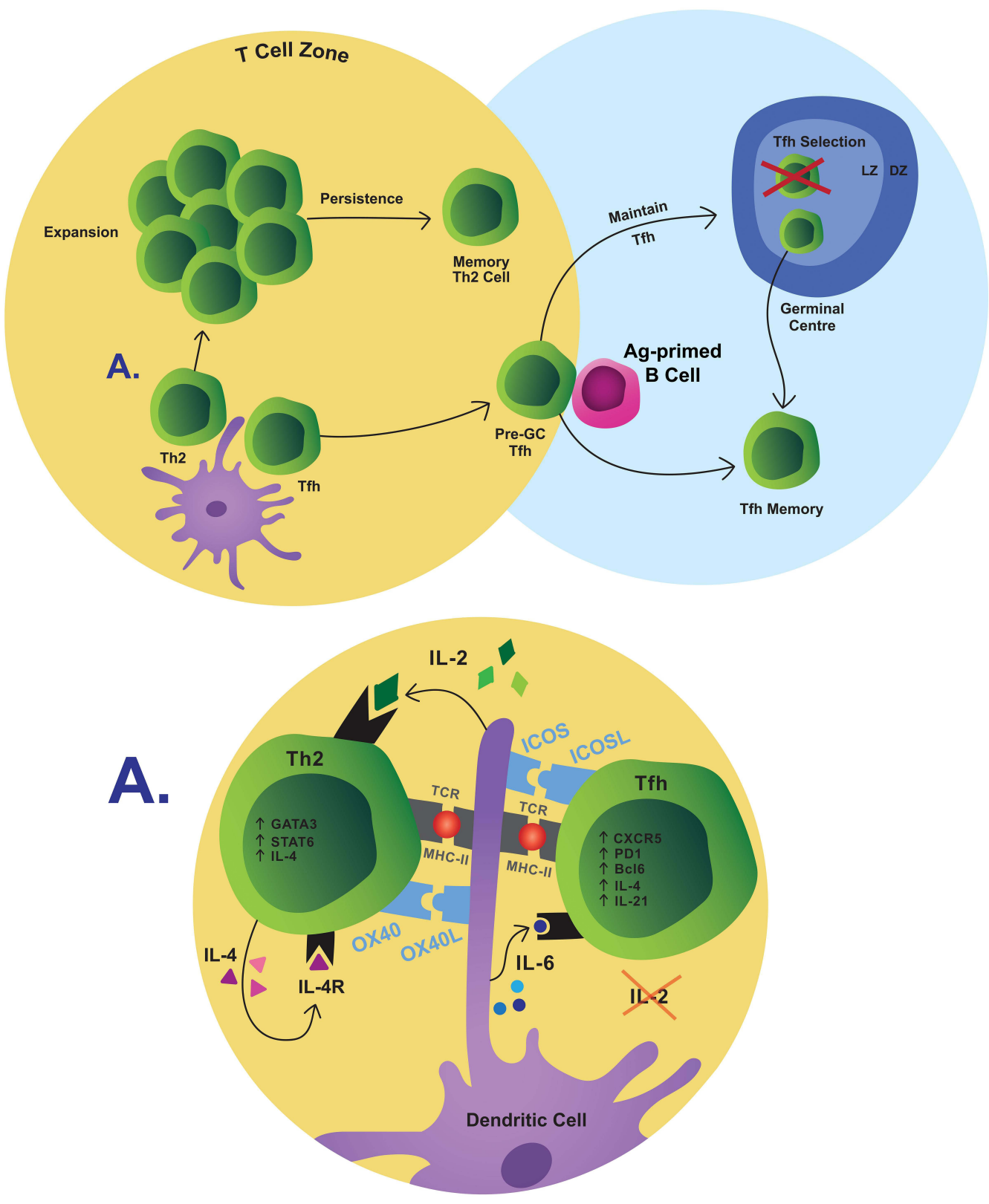

Figure I Simplified pathway of memory T-cell differentiation. T-cell fate is decided in part by interactions with DCs. Th2 cells expand and contract, the remaining of which are retained as memory. Tfh maturation continues when they interact with B cells at the T/B border and when selected over the course of a GC reaction. Some of these cells persist as memory Tfh cells.

Abbreviations:Ag, antigen; $\mathrm{LZ}$, light zone; DZ, dark zone.

commit to this phenotype. ${ }^{54}$ New evidence indicates that $\mathrm{Tfh}$ cells are dynamically selected in the GC. ${ }^{74}$ Some Tfh cells are selected to persist into a memory fate, wherein maintenance of long-lived Tfh cells requires continued Bcl6 expression and ICOS signaling. ${ }^{75,76}$ The role of memory Tfh cells in food allergy has not been assessed, although this research is relevant given the connection of Th cells with B-cell activation and $\operatorname{IgE}$ generation.

The priming site and the localization of Th2 differentiation in specific SLOs influence allergic T-cell memory formation. ${ }^{77,78}$ Activation imprints Th2 cells with differential homing patterns that guide their trafficking to specific sites as they enter the memory pool. ${ }^{77}$ Memory $\mathrm{T}$ cells are not restricted to the circulation, even when first activated in the SLOs, and tissue-resident memory T (Trm) cells can survey non-lymphoid tissues following the primary response. ${ }^{78-80} \mathrm{In}$ mice with allergic asthma, long-lived lung-resident $\mathrm{CD}^{+} \mathrm{Trm}$ cells are sufficient to induce airway hyperreactivity. ${ }^{81,82}$ Whether Trm cells are seeded following primary allergen exposure and perform a similar role in food allergy remains 
unknown. Nevertheless, Trm cells are reported to accumulate in the intestines during prolonged antigen exposure, and their low threshold for local reactivation could coordinate a rapid initiation of secondary responses which are often accompanied by symptoms localized to specific tissues. ${ }^{78,81,83}$

\section{Generation of Allergen-Specific Memory B Cells}

The generation of allergen-specific MBCs is T-cell dependent. Naive B cells capture allergen from subcapsular macrophages, which sequester allergen from incoming lymph drainage (Figure 2A). ${ }^{84}$ Naive B cells internalize allergens for presentation and migrate to the border of the $\mathrm{B}$ cell follicle and the $\mathrm{T}$ cell zone. There they engage with activated $\mathrm{CD}^{+} \mathrm{T}$ cells, likely $\mathrm{Tfh}$ or pre-GC $\mathrm{Tfh}$ cells rather than Th2 cells (Figure 2B). ${ }^{52,53,85}$ The Tfh/B cell synapse and the fate decisions which follow likely represent a crucial moment in the generation of allergic MBCs and IgE. Naive B cells and Tfh cells interact using a variety of signals, including MHC-II:TCR, CD40/ CD40L, ICOS/ICOSL, SAP/SLAM and various cytokine signals which activate the $\mathrm{B}$ cell (Figure $2 \mathrm{~B}) .^{73,86}$

Newly activated B cells adopt a transient $\mathrm{CD} 38^{+} \mathrm{GL} 7^{+}$ phenotype that predates GC B cells or extrafollicular MBC differentiation (Figure 2C). ${ }^{87}$ Recent evidence suggests that CSR is initiated during early interactions at the T/B cell border, possibly during this intermediate stage, rather than in the GC as classically believed. ${ }^{88}$ Indeed, even without GCs, Tfh cells are the critical source of IL-4, which suggests that IgE CSR is likely instructed at the T/B border, early in B-cell activation. ${ }^{52,53}$ IgG1 CSR, however, occurs in the absence of Tfh-derived IL-4 and,

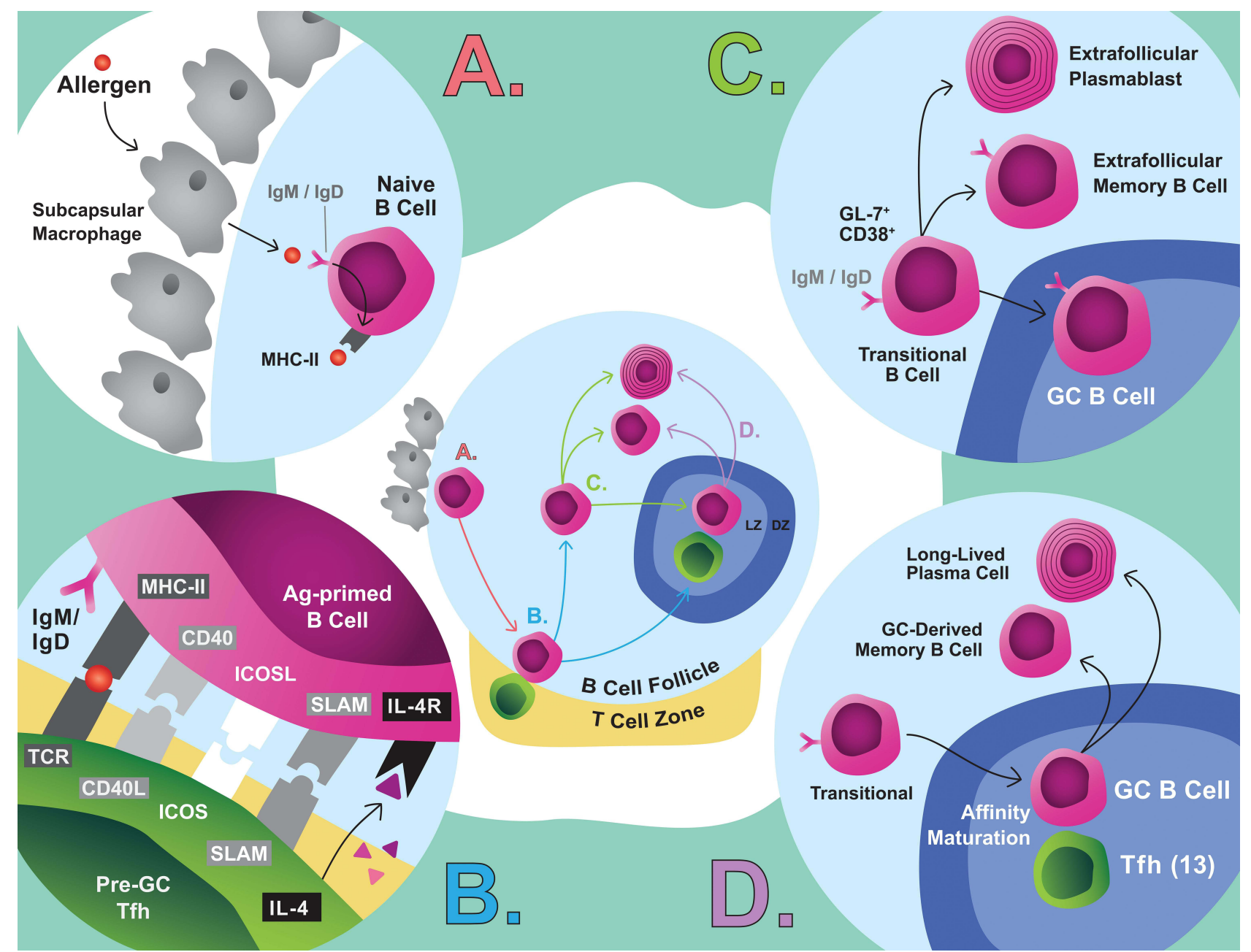

Figure 2 Simplified pathway of MBC differentiation. (A) Naive B cells capture antigen from subcapsular macrophages, which initiates differentiation. (B) These cells are activated by pre-GC Tfh cells. (C) These cells enter an intermediate phase where extrafollicular fate decisions are made, or the cells migrate to the GC. (D) GC B cells affinity mature and are selected through interactions with Tfh cells to leave the GC as a MBC or LLPC.

Abbreviation:Ag, antigen. 
therefore, it is plausible that $\operatorname{IgG1} 1^{+} \mathrm{MBCs}$, the relevant precursors of secondary IgE, could be seeded independently of Tfh-derived IL- $4{ }^{53}$ Furthermore, the precursors of tissue-resident $\mathrm{MBCs}$ are thought to be generated early in B-cell activation and $\mathrm{IgE}^{+} \mathrm{PC}$ differentiation is also thought to primarily occur extrafollicularly. ${ }^{89,90}$ Then, it is clear that the early stages are crucial for B-cell fate decisions, but the signals that drive these various fates remain poorly understood.

Activated B cells that acquire a GC phenotype migrate deep into B-cell follicles to establish or join a GC (Figure 2D). The GC selection dynamics are intricate and have been reviewed elsewhere. ${ }^{85,91}$ The primary reservoir of mature $\mathrm{MBCs}\left(\mathrm{CD} 80^{+} \mathrm{CD} 73^{+} \mathrm{PDL} 2^{+}\right)$which yields secondary $\mathrm{IgE}$ appears to be GC-derived. ${ }^{87,92}$ Allergenspecific $\mathrm{IgE}^{+} / \mathrm{IgG}^{+}$cells generally exhibit high-affinity mutations with an enrichment of replacement mutations in the CDR domains of their BCRs, which is indicative of affinity-driven selection. ${ }^{8,13}$ Although under some circumstances extrafollicular affinity maturation can occur, ${ }^{93}$ the maturity and high-mutation frequency of allergen-specific MBCs suggest that they are GC-derived. ${ }^{13,15,19}$ Intriguingly, IgE-expressing cells poorly survive in GCs because, among other reasons, tonic IgE BCR signalling induces PC differentiation. ${ }^{94-96}$ The survival of $\mathrm{IgE}^{+} \mathrm{GC}$ B cells appears to be under the control of Tfh13 cells localized within the GC, which drive high-affinity $\operatorname{IgE}$ responses associated with anaphylaxis. ${ }^{54}$ Ultimately, the importance of the GC in food allergy remains unclear given that GC-deficient mice generate anaphylactic IgE upon allergic sensitization and have IgE recall responses. ${ }^{13}$

\section{Memory Reconstitution of Allergy}

Allergen avoidance results in a decline in IgE. However, humoral IgE immunity is rapidly regained upon reactivation of immune memory. ${ }^{13}$ As aforementioned, allergenspecific IgE-expressing MBCs exist rarely - or not at all and $\mathrm{IgE}^{+}$PCs are short-lived. ${ }^{9}$ Thus, there are at least 2 critical components of secondary IgE responses: a CSR event and, subsequently, PC differentiation (Figure 3). In a primary response, most $\mathrm{IgE}^{+} \mathrm{PCs}$ are thought to be derived following CSR in extrafollicular foci. ${ }^{90}$ In the incipient stages of food allergy, immature, pro-GC $\operatorname{IgG} 1^{+}$ MBCs (PDL-2 ${ }^{-} \mathrm{CD} 80^{-} \mathrm{CD} 35^{+} \mathrm{CD} 73^{+}$) are established. ${ }^{15}$ This subset re-enters the $\mathrm{GC}$ on recall to yield $\mathrm{IgE}^{+} \mathrm{GC}$ $\mathrm{B}$ cells and may subsequently generate IgE ${ }^{+} \mathrm{PCs}^{15}{ }^{15}$ upon subsequent allergen exposures, affinity matured $\operatorname{IgG} 1^{+}$ MBCs become the most populous MBC and the foremost contributors to secondary IgE production without re-entry into GCs. ${ }^{13,19}$

Secondary B-cell responses in allergy are also strictly $\mathrm{T}$ cell-dependent. ${ }^{56,97}$ During recall, MBCs likely have a pronounced role in allergen presentation because the higher-affinity BCRs would enable efficient allergen capture even at low concentrations. ${ }^{98}$ The absence of $\mathrm{CD} 4^{+}$ $\mathrm{T}$ cells in a secondary response to food allergens prevents IgE production and clinical reactivity. ${ }^{13,21}$ That being said, MBC activation does not require antigen-experienced $\mathrm{CD}^{+} \mathrm{T}$ cells, but rather naive $\mathrm{CD}^{+} \mathrm{T}$ cells are sufficient, ${ }^{99}$ although how they become competent in driving type 2 responses is not well defined. One hypothesis is that allergen-specific MBCs retain intrinsic properties, such as a Th2-like polarization, enabling the maintenance of future de novo Th2 responses. ${ }^{100}$ Although naive $\mathrm{CD} 4{ }^{+}$ $\mathrm{T}$ cells together with MBCs are sufficient for secondary responses in experimental systems, the contribution of naive $\mathrm{CD}^{+} \mathrm{T}$ cells in a competitive environment (i.e. presence of memory $\mathrm{CD} 4^{+} \mathrm{T}$ cells) remains in question.

IL-4 is a fundamental requirement for IgE CSR. ${ }^{101,102}$ In both mice and humans, antibody-mediated blockade of the IL-4R $\alpha$ chain abrogates IgE production in secondary responses. $^{21,101,103}$ Most leukocytes produce IL-4, but a significant contribution from non-T cells in CSR is unlikely. In fact, the use of IL-4 reporter mice demonstrated that $\mathrm{CD}^{+} \mathrm{T}$ cells provide the majority of IL-4 in primary and secondary responses, with some contribution from both Tfh and Th2 cells. ${ }^{21,103}$ IL-13 also engages IL$4 \mathrm{R} \alpha$, although $\operatorname{IgE} \mathrm{CSR}$ is intact in IL-13-deficient mice. ${ }^{104}$ On the other hand, IL-13 may play a nonredundant role in high-affinity IgE production, particularly in secondary responses that engage low-affinity MBC clones, or naive B cells which in some systems are reported to be the predominant source of secondary GC B cells. ${ }^{54}$

Beyond IL-4, it is plausible that other $\mathrm{CD}^{+}{ }^{+} \mathrm{T}$ cellderived signals are critical for IgE reactivation. In primary responses, antigen-primed $\mathrm{B}$ cells and $\mathrm{CD} 4{ }^{+} \mathrm{T}$ cells further interact through costimulatory molecules such as CD40, ICOS and OX $40 .{ }^{105}$ In patients with hyper IgM syndrome, deficiencies in $\operatorname{IgG}, \operatorname{Ig} A$, and $\operatorname{IgE}$ are observed due to CD40L mutations that prevent CSR. ${ }^{106} \mathrm{PN}$-stimulation of allergic splenocytes under CD40L-blockade, however, did not compromise MBC proliferation. ${ }^{13}$ Thus, it is possible that $\mathrm{MBCs}$ retain the requirement for $\mathrm{CD} 40$ engagement to undergo IgE CSR, but not for PC differentiation. 


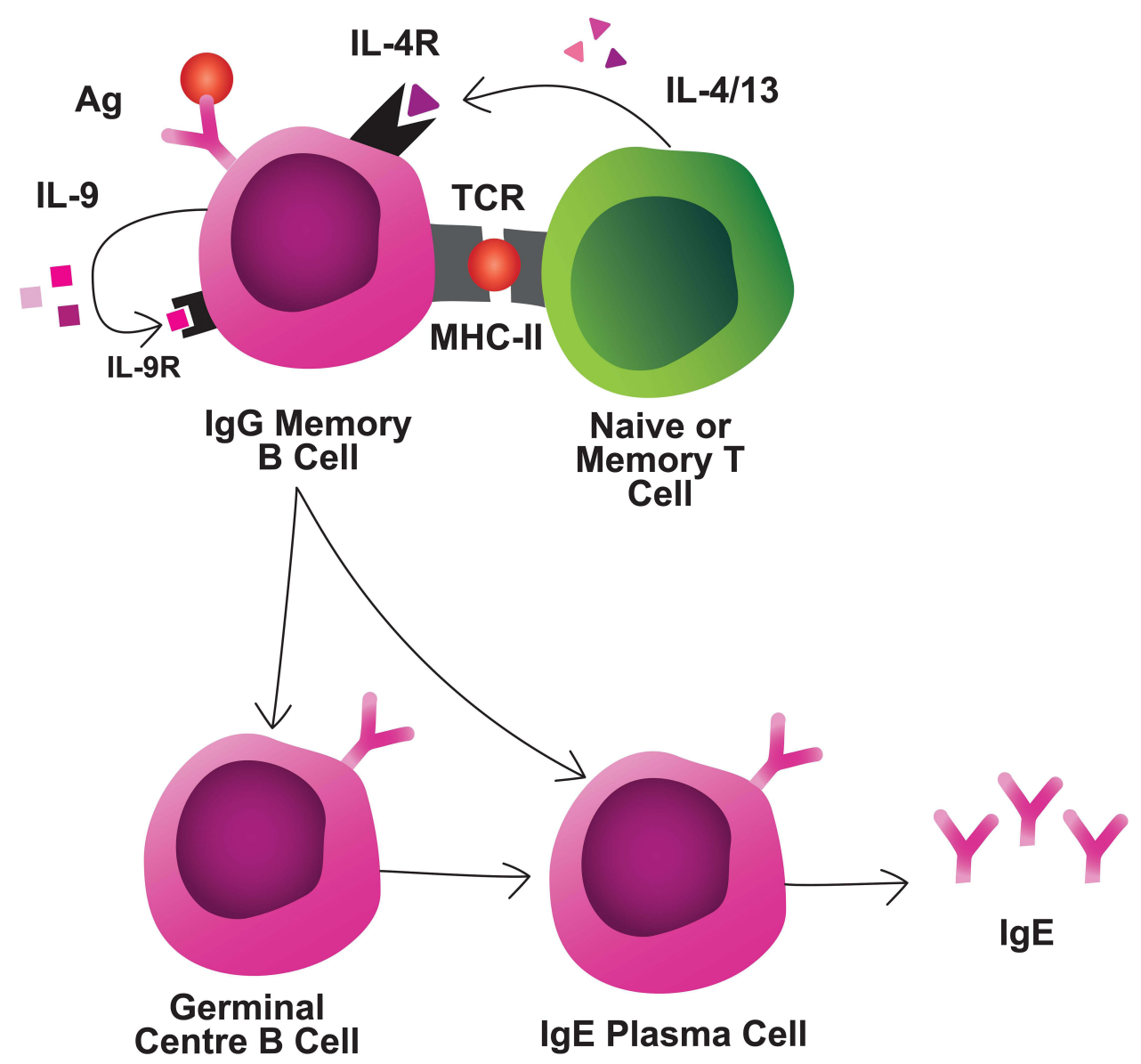

Figure 3 Interactions during memory reactivation. MBCs interact with naive or memory T cells through TCR/MHC and IL-4/IL-4R interactions, at a minimum. MBCs secrete autocrine/paracrine IL-9 which is required for MBC reactivation. MBCs can differentiate rapidly into IgE-secreting PCs, or first enter GCs for additional diversification prior to IgE PC differentiation.

Abbreviation:Ag, antigen.

ICOS-ICOSL interactions are important because ICOS-deficient mice exhibit defective IL-4 production and impaired IgE responses following KLH-alum immunization. ${ }^{107}$ Also, in secondary responses, expansion of antigen-specific B cells and class-switched antibody responses are compromised in the absence of ICOS signaling. ${ }^{73,108}$ The fact that ICOS is essential for the maintenance of the memory $\mathrm{Tfh}$ cell phenotype ${ }^{108}$ may explain the impaired secondary responses observed with ICOSL blockade. ${ }^{75}$

Regarding OX40, OX40L-expressing DCs promote Th2 polarization, although OX40L blockade in secondary responses does not appear to skew the Th2 phenotype $^{56,109}$ Rather, loss of OX40 signaling prior to allergen rechallenge compromised the accumulation and survival of reactivated $\mathrm{T}$ cells and the $\operatorname{IgE}$ boost. ${ }^{109}$
Whether the OX40-OX40L interaction is occurring between $\mathrm{T}$ cells and DCs and/or B cells is unclear.

Forms of non-T-cell-mediated-help may also regulate the MBC response. Notably, IL-9R signaling in MBCs is required for a robust secondary humoral response, though T cells are not the critical source of IL-9 in this context. ${ }^{110}$ While the source of biologically-relevant IL-9 is unknown, MBCs appear to produce large amounts of IL-9 during a recall response suggesting autocrine regulation of reactivation. Altogether, studies of the requirements for $\mathrm{MBC}$ reactivation are scarce and further investigation is warranted, specially at the tissue level.

Tissue-resident MBCs are thought to contribute to secondary IgE responses in food allergic patients, but this has not yet been adequately proven. Food-allergic mice have local Th2 cytokine production upon allergen challenge, 
which persists when lymphocyte migration is inhibited, indicating the presence of Trm cells. ${ }^{111}$ Further, CSR is observed in mucosal tissues in allergic patients and local $\operatorname{IgE}$ production is reported to mediate food-induced abdominal pain. ${ }^{112}$ Taken together, these data indicate that resident memory populations may meaningfully contribute to disease-relevant $\operatorname{IgE}$ reactivation.

Immunological memory within SLOs is better understood. Memory B and T cells are readily detected in these organs and position themselves in strategic locations to induce a potent secondary response. MBCs maximize the likelihood of antigen encounter by residing in the marginal zone of the spleen and in the subcapsular sinus of the lymph node. ${ }^{113}$ These locations are rich with $\mathrm{CD} 169^{+}$ macrophages which, as abovementioned, capture allergens and transfer them to nearby B cells. Upon allergen encounter, these cells proliferate and generate foci in which they differentiate primarily into MBCs and PCs, but also into secondary GC B cells for additional diversification. ${ }^{113,114}$ Additional research is required to discern the relevant locations of MBC reactivation and secondary IgE CSR in food allergy.

The immune system also retains mechanisms to regulate $\mathrm{IgE}$ responses such as the generation of Treg cells. For example, in humans, spontaneous and AIT-induced desensitization to food allergens is associated with increased Treg-cell frequency. ${ }^{115,116}$ Adoptive transfer of Treg cells into allergic mice suppresses $\operatorname{IgE}$ production and anaphylaxis. ${ }^{49}$ Treg cells perform a number of inhibitory functions (IL-10 production, dephosphorylation of ATP to adenosine, etc.), though their impact on $\mathrm{MBC}$ reactivation is likely indirect via $\mathrm{CD} 4^{+} \mathrm{T}$-cell suppression.

Over the last decade, $\mathrm{T}$ follicular regulatory (Tfr) cells have emerged as key regulators of humoral immunity. Tfr cells share functional characteristics with Treg cells, and localize to T-B cell borders and GCs akin to Tfh cells. ${ }^{117}$ Their location enables direct suppression of Tfh and GC B-cell activity. Genetic deletion of Tfr cells in mice results in heightened $\operatorname{IgE}^{+}$PC frequency and allergen-specific $\operatorname{IgE}$ titers. ${ }^{118}$ In stark contrast, a different Tfr knockout model has shown an impairment of allergen-specific IgE production, possibly due to loss of Tfr-derived IL-10. ${ }^{119}$ In humans, IL-10-secreting CD25 ${ }^{+}$FOXP3 $^{-}$Tfh cells, but not Tfr cells, are inversely correlated with serum $\operatorname{IgE}$ titers. ${ }^{120}$ Whether inhibitory or promoting functions are carried out by Tfr cells in secondary responses needs to be elucidated. Tfh cells themselves can also suppress IgE responses through IL-21, which inhibits $\operatorname{IgE}$ CSR. ${ }^{121}$
Congruently, Th2-associated Tfh13 cells secrete less IL21 relative to Th1-associated Tfh cells. ${ }^{54}$ The inhibitory effects of IL-21, however, are attenuated by high levels of CD40 signaling. ${ }^{121}$

Lastly, a form of non-T-cell-mediated-regulation may be carried out by regulatory B cells, which are a heterogeneous group of B cells and certain subsets of PCs. ${ }^{122}$ Regulatory B cells suppress the activity of effector $\mathrm{T}$ cells and promote Treg cell differentiation primarily via IL-10. ${ }^{123,124}$ However, they can secrete other soluble molecules with regulatory roles (TGF- $\beta$, IL-35, TSP-1, IDO, etc.) and express surface-bound molecules that enable immunosuppressive cellular interactions (PD-1, FASL, CD73, CD9, CD1d, etc.). ${ }^{125}$ AIT increases B-regulatory cell frequency, which may further promote Treg cell differentiation and, subsequently, Treg-mediated immunosuppression. ${ }^{125-128}$

In summary, few studies have assessed the cellular and molecular requirements for secondary responses to allergens. Clearly defining the requirements for MBC reactivation is necessary for the identification of targets for therapeutic intervention. An insightful approach by which to address this issue would be through computational modelling of cell-cell interactions from single-cell transcriptomic data followed by in vivo validation, as has been performed in other diseases. Moreover, investigating intrinsic regulators of secondary $\operatorname{IgE}$ immunity may inspire therapeutic approaches to augment these mechanisms.

\section{Conclusion}

Recalling Thucydides: "They had no fear for themselves for the same man was never attacked twice-never at least fatally". Paradoxically, patients with food allergies constantly fear for themselves as re-exposures to allergens unleash allergic reactions. Thus, immune memory is a double-edged sword, beneficial in some instances and harmful in others. That paradox transcends to research directions and goals. Whereas the main goal of furthering our understanding of immune memory in the context of Th1-IgG immunity is to enhance strength and persistent activation, such as is the case in vaccination, the main goal in the context of Th2-IgE immunity to both food and aeroallergens is precisely to weaken or dismantle it.

Despite recent advances, understanding the mechanisms that reactivate memory in food allergy and, therefore, make some food allergies persistent remains vastly incomplete. Specifically, the cellular and molecular interactions 
that take place between MBCs and T cells, whether naive or memory $\mathrm{T}$ cells, and other cells has not been yet established.

Answering this question is challenging because there are substantial knowledge gaps that leave researchers with critical questions. Where do memory cells reside and become reactivated? How many phenotypes of allergen-specific memory $\mathrm{B}$ and $\mathrm{T}$ cells exist? Within the same lineage, what is the trajectory of these phenotypes? What is the extent of plasticity among these phenotypes? Can immune responses in food allergy be reprogrammed and, if so, through what mechanism? Is the persistence of food allergy the result of a failure of regulatory mechanisms (Treg or Tfr cells)? Answers to these questions will not only illuminate our fundamental immunological understanding of food allergy but also contribute to the identification of targets for therapeutic intervention.

\section{Abbreviations}

PCs, plasma cells; MBCs, memory B cells; PBMCs, peripheral blood mononuclear cells; CSR, class-switch recombination; BCRs, B-cell receptors; OVA, ovalbumin; SLOs, secondary lymphoid organs; PN, peanut; AIT, allergen immunotherapy; sc-RNAseq, single-cell RNA sequencing; DCs, dendritic cells; TCR, T-cell receptor; Treg, $\mathrm{T}$ regulatory; $\mathrm{Tfh}, \mathrm{T}$ follicular helper; $\mathrm{Tfr}, \mathrm{T}$ follicular regulatory; Trm, tissue-resident memory.

\section{Acknowledgments}

We acknowledge Adam Wade-Vallance and Claud Spadafora for critically reviewing the manuscript and for illustrating the figures, respectively. RJS acknowledges the support received by the Severo Ochoa Program (AEI/SEV2017-0712), FSE/FEDER through the Instituto de Salud Carlos III (ISCIII; CP20/00043), The Nutricia Research Foundation (NRF-2021-13) and New Frontiers in Research Fund (NFRFE-2019-00083). Research in MJ's laboratory is supported by funds from Food Allergy Canada, Walter and Maria Schroeder Foundation, Michael Zych Family, the Canadian Asthma, Allergy, and Immunology Foundation (CAAIF) and ALK-Abello.

\section{Disclosure}

JFEK, KB, AP, EG and MJ report grants from Food Allergy Canada,the Walter and Maria Schroeder Foundation, the Michael Zych Family, the Canadian Asthma Allergy and Immunology Foundation, and ALK-

Abello, outside the submitted work. The authors report no other potential conflicts of interest in relation to this work.

\section{References}

1. Tritle LA. A New History of the Peloponnesian War. Wiley Online Library; 2010.

2. Bruton K, Koenig JFE, Phelps A, Jordana M. Perturbations to homeostasis in experimental models revealed innate pathways driving food allergy. Front Immunol. 2020;11:603272. doi:10.3389/fimmu.2020.603272

3. Florsheim EB, Sullivan ZA, Khoury-Hanold W, Medzhitov R. Food allergy as a biological food quality control system. Cell. 2021;184(6):1440-1454. doi:10.1016/j.cell.2020.12.007

4. Savage J, Sicherer S, Wood R. The natural history of food allergy. J Allergy Clin Immunol Pract. 2016;4(2):196-203; quiz 204. doi:10.1016/j.jaip.2015.11.024

5. Jiménez-Saiz R, Chu DK, Waserman $\mathrm{S}$, Jordana M. Initiation, persistence and exacerbation of food allergy. In: Schmidt-Weber CB, editor. Allergy Prevention and Exacerbation. Cham: Springer International Publishing; 2017:121-144.

6. Amanna IJ, Carlson NE, Slifka MK. Duration of humoral immunity to common viral and vaccine antigens. $N$ Engl J Med. 2007;357(19):1903-1915. doi:10.1056/NEJMoa066092

7. Winter O, Dame C, Jundt F, Hiepe F. Pathogenic long-lived plasma cells and their survival niches in autoimmunity, malignancy, and allergy. $J$ Immunol. 2012;189(11):5105-5111. doi:10.4049/jimmunol.1202317

8. Luger EO, Wegmann M, Achatz G, Worm M, Renz H, Radbruch A. Allergy for a lifetime? Allergol Int. 2010;59 (1):1-8. doi:10.2332/allergolint.10-RAI-0175

9. Jimenez-Saiz R, Bruton K, Koenig JFE, Waserman S, Jordana M. The IgE memory reservoir in food allergy. J Allergy Clin Immunol. 2018;142(5):1441-1443. doi:10.1016/j.jaci.2018.08.029

10. Carballeda-Sangiao N, Rodriguez-Mahillo AI, Careche M, Navas A, Moneo I, Gonzalez-Munoz M. Changes over time in $\operatorname{IgE}$ sensitization to allergens of the fish parasite Anisakis spp. PLoS Negl Trop Dis. 2016;10(7):e004864. doi:10.1371/journal. pntd.0004864

11. Kim MS, Straesser MD, Keshavarz B, et al. IgE to galactose-alpha-1,3-galactose wanes over time in patients who avoid tick bites. J Allergy Clin Immunol Pract. 2020;8(1):364367 e362. doi:10.1016/j.jaip.2019.08.045

12. Jimenez-Saiz R, Chu DK, Mandur TS, et al. Lifelong memory responses perpetuate humoral $\mathrm{TH} 2$ immunity and anaphylaxis in food allergy. J Allergy Clin Immunol. 2017;140(6):1604-1615 e1605. doi:10.1016/j.jaci.2017.01.018

13. Bernasconi NL, Traggiai E, Lanzavecchia A. Maintenance of serological memory by polyclonal activation of human memory B cells. Science. 2002;298(5601):2199-2202. doi:10.1126/ science. 1076071

14. Jimenez-Saiz R, Ellenbogen Y, Koenig JFE, et al. IgG1(+) B-cell immunity predates IgE responses in epicutaneous sensitization to foods. Allergy. 2019;74(1):165-175. doi:10.1111/all.13481

15. Asrat S, Kaur N, Liu X, et al. Chronic allergen exposure drives accumulation of long-lived IgE plasma cells in the bone marrow, giving rise to serological memory. Sci Immunol. 2020;5(43): eaav8402. doi:10.1126/sciimmunol.aav8402

16. Jimenez-Saiz R, Ellenbogen $\mathrm{Y}$, Bruton $\mathrm{K}$, et al. Human BCR analysis of single-sorted, putative $\operatorname{IgE}(+)$ memory B cells in food allergy. J Allergy Clin Immunol. 2019;144(1):336-339 e336. doi:10.1016/j.jaci.2019.04.001

17. Looney TJ, Lee JY, Roskin KM, et al. Human B-cell isotype switching origins of IgE. J Allergy Clin Immunol. 2016;137 (2):579-586 e577. doi:10.1016/j.jaci.2015.07.014

18. He JS, Subramaniam S, Narang V, et al. IgG1 memory B cells keep the memory of IgE responses. Nat Commun. 2017;8(1):641. doi:10.1038/s41467-017-00723-0 
19. Turqueti-Neves A, Otte M, Schwartz C, et al. The extracellular domains of IgG1 and T cell-derived IL-4/IL-13 are critical for the polyclonal memory IgE response in vivo. PLoS Biol. 2015;13 (11):e1002290. doi:10.1371/journal.pbio. 1002290

20. Bruton K, Spill P, Vohra S, et al. Interrupting reactivation of immunologic memory diverts the allergic response and prevents anaphylaxis. J Allergy Clin Immunol. 2020. doi:10.1016/j. jaci.2020.11.042

21. Prussin C, Lee J, Foster B. Eosinophilic gastrointestinal disease and peanut allergy are alternatively associated with IL-5+ and IL-5(-) T(H)2 responses. J Allergy Clin Immunol. 2009;124 (6):1326-1332 e1326. doi:10.1016/j.jaci.2009.09.048

22. DeLong JH, Simpson KH, Wambre E, James EA, Robinson D, Kwok WW. Ara h 1-reactive T cells in individuals with peanut allergy. J Allergy Clin Immunol. 2011;127(5):1211-1218 e1213. doi:10.1016/j.jaci.2011.02.028

23. Patil SU, Ogunniyi AO, Calatroni A, et al. Peanut oral immunotherapy transiently expands circulating Ara h 2-specific B cells with a homologous repertoire in unrelated subjects. J Allergy Clin Immunol. 2015;136(1):125-134 e112. doi:10.1016/j. jaci.2015.03.026

24. Hoh RA, Joshi SA, Lee JY, et al. Origins and clonal convergence of gastrointestinal $\operatorname{IgE}(+)$ B cells in human peanut allergy. Sci Immunol. 2020;5(45):eaay4209. doi:10.1126/sciimmunol.aay4209

25. Soleto-Fernandez I, Jimenez-Saiz R, Carrasco YR. Enlightening human B-cell diversity. Allergy. 2020. doi:10.1111/all.14685

26. Glass DR, Tsai AG, Oliveria JP, et al. An Integrated Multi-omic Single-Cell Atlas of Human B Cell Identity. Immunity. 2020;53 (1):217-232 e215. doi:10.1016/j.immuni.2020.06.013

27. Jimenez-Saiz R, Molina E, Lopez-Exposito I. Peanut allergy: allergens and etiology. In: Lopez-Exposito I, Blazquez AB, editors. Peanuts: Bioactivities and Allergies. NOVA; 2013:137-152.

28. Hemmings O, Du Toit G, Radulovic S, Lack G, Santos AF. Ara $\mathrm{h} 2$ is the dominant peanut allergen despite similarities with Ara $\mathrm{h}$ 6. $J$ Allergy Clin Immunol. 2020;146(3):621-630 e625. doi:10.1016/j.jaci.2020.03.026

29. Hoh RA, Joshi SA, Liu Y, et al. Single B-cell deconvolution of peanut-specific antibody responses in allergic patients. $J$ Allergy Clin Immunol. 2016;137(1):157-167. doi:10.1016/j. jaci.2015.05.029

30. Croote D, Darmanis S, Nadeau KC, Quake SR. High-affinity allergen-specific human antibodies cloned from single $\mathrm{IgE}$ B cell transcriptomes. Science. 2018;362(6420):1306-1309. doi:10.1126/science.aau2599

31. Levin M, King JJ, Glanville J, et al. Persistence and evolution of allergen-specific IgE repertoires during subcutaneous specific immunotherapy. $J$ Allergy Clin Immunol. 2016;137 (5):1535-1544. doi:10.1016/j.jaci.2015.09.027

32. Ehlers A, den Hartog Jager C, Knulst A, Otten H. Distinction between peanut allergy and tolerance by characterization of B-cell receptor repertoires. Authorea Preprints. 2020.

33. Dolton G, Tungatt K, Lloyd A, et al. More tricks with tetramers: a practical guide to staining $\mathrm{T}$ cells with peptide-MHC multimers. Immunology. 2015;146(1):11-22. doi:10.1111/imm.12499

34. Pascal M, Konstantinou GN, Masilamani M, Lieberman J, Sampson HA. In silico prediction of Ara h $2 \mathrm{~T}$ cell epitopes in peanut-allergic children. Clin Exp Allergy. 2013;43(1):116-127. doi:10.1111/cea. 12014

35. Novak EJ, Liu AW, Gebe JA, et al. Tetramer-guided epitope mapping: rapid identification and characterization of immunodominant CD4+ T cell epitopes from complex antigens. J Immunol. 2001;166(11):6665-6670. doi:10.4049/jimmunol.166.11.6665

36. Chattopadhyay PK, Yu J, Roederer M. Live-cell assay to detect antigen-specific CD4+ T-cell responses by CD154 expression. Nat Protoc. 2006;1(1):1-6. doi:10.1038/nprot.2006.1
37. Ruiter B, Smith NP, Monian B, et al. Expansion of the CD4(+) effector T-cell repertoire characterizes peanut-allergic patients with heightened clinical sensitivity. J Allergy Clin Immunol. 2020;145(1):270-282. doi:10.1016/j.jaci.2019.09.033

38. Van Hemelen D, Mahler V, Fischer G, et al. HLA class II peptide tetramers vs allergen-induced proliferation for identification of allergen-specific CD4 T cells. Allergy. 2015;70(1):49-58. doi:10.1111/all.12524

39. Begin P, Nadeau KC. Changes in peanut-specific T-cell clonotype with oral immunotherapy. J Allergy Clin Immunol. 2015;135 (6):1636-1638. doi:10.1016/j.jaci.2015.03.010

40. Tu AA, Gierahn TM, Monian B, et al. TCR sequencing paired with massively parallel $3^{\prime}$ RNA-seq reveals clonotypic T cell signatures. Nat Immunol. 2019;20(12):1692-1699. doi:10.1038/ s41590-019-0544-5

41. Hintzen RQ, de Jong R, Lens SM, Brouwer M, Baars P, van Lier RA. Regulation of CD27 expression on subsets of mature T-lymphocytes. J Immunol. 1993;151(5):2426-2435.

42. Wambre E, Bajzik V, DeLong JH, et al. A phenotypically and functionally distinct human $\mathrm{TH} 2$ cell subpopulation is associated with allergic disorders. Sci Transl Med. 2017;9(401). doi:10.1126/ scitranslmed.aam9171

43. Wambre E, James EA, Kwok WW. Characterization of CD4+ $\mathrm{T}$ cell subsets in allergy. Curr Opin Immunol. 2012;24 (6):700-706. doi:10.1016/j.coi.2012.07.009

44. Wambre E, DeLong JH, James EA, LaFond RE, Robinson D, Kwok WW. Differentiation stage determines pathologic and protective allergen-specific CD4+ T-cell outcomes during specific immunotherapy. J Allergy Clin Immunol. 2012;129(2):544-551, 551 e541-547. doi:10.1016/j.jaci.2011.08.034

45. Chiang D, Chen X, Jones SM, et al. Single-cell profiling of peanut-responsive $\mathrm{T}$ cells in patients with peanut allergy reveals heterogeneous effector TH2 subsets. J Allergy Clin Immunol. 2018;141(6):2107-2120. doi:10.1016/j.jaci.2017.11.060

46. Blom LH, Martel BC, Larsen LF, et al. The immunoglobulin superfamily member CD200R identifies cells involved in type 2 immune responses. Allergy. 2017;72(7):1081-1090. doi:10.1111/ all.13129

47. Bangert C, Rindler K, Krausgruber T, et al. Persistence of mature dendritic cells, TH2A, and $\mathrm{Tc} 2$ cells characterize clinically resolved atopic dermatitis under IL-4Ralpha blockade. Sci Immunol. 2021;6(55):eabe2749. doi:10.1126/sciimmunol.abe2749

48. Noval Rivas M, Burton OT, Wise P, et al. Regulatory $\mathrm{T}$ cell reprogramming toward a Th2-cell-like lineage impairs oral tolerance and promotes food allergy. Immunity. 2015;42(3):512-523. doi:10.1016/j.immuni.2015.02.004

49. Cosmi L, Maggi L, Santarlasci V, et al. Identification of a novel subset of human circulating memory $\mathrm{CD} 4(+) \mathrm{T}$ cells that produce both IL-17A and IL-4. J Allergy Clin Immunol. 2010;125(1):222-230 e221-224. doi:10.1016/j.jaci.2009.10.012

50. Spergel J, Aceves SS. Allergic components of eosinophilic esophagitis. $J$ Allergy Clin Immunol. 2018;142(1):1-8. doi:10.1016/j.jaci.2018.05.001

51. Kobayashi T, Iijima K, Dent AL, Kita H. Follicular helper T cells mediate IgE antibody response to airborne allergens. $J$ Allergy Clin Immunol. 2017;139(1):300-313 e307. doi:10.1016/j.jaci.2016.04.021

52. Meli AP, Fontes G, Leung Soo C, King IL. T follicular helper cell-derived IL-4 is required for IgE production during intestinal helminth infection. $J$ Immunol. 2017;199(1):244-252. doi:10.4049/jimmunol.1700141

53. Gowthaman U, Chen JS, Zhang B, et al. Identification of a $\mathrm{T}$ follicular helper cell subset that drives anaphylactic IgE. Science. 2019;365(6456):eaaw6433. doi:10.1126/science.aaw6433

54. Jimenez-Saiz R, Bruton K, Jordana M. Follicular T cells: from stability to failure. Allergy. 2020;75(4):1006-1007. doi:10.1111/ all.14167 
55. Chu DK, Mohammed-Ali Z, Jimenez-Saiz R, et al. T helper cell IL-4 drives intestinal Th2 priming to oral peanut antigen, under the control of OX40L and independent of innate-like lymphocytes. Mucosal Immunol. 2014;7(6):1395-1404. doi:10.1038/mi.2014.29

56. Chu DK, Jimenez-Saiz R, Verschoor CP, et al. Indigenous enteric eosinophils control DCs to initiate a primary Th2 immune response in vivo. $J$ Exp Med. 2014;211(8):1657-1672. doi:10.1084/jem.20131800

57. Ellenbogen Y, Jimenez-Saiz R, Spill P, Chu DK, Waserman S, Jordana M. The Initiation of Th2 immunity towards food allergens. Int $J$ Mol Sci. 2018;19(5):1447. doi:10.3390/ ijms 19051447

58. Ruiter B, Shreffler WG. Innate immunostimulatory properties of allergens and their relevance to food allergy. Semin Immunopathol. 2012;34(5):617-632. doi:10.1007/s00281-0120334-8

59. McKinstry KK, Strutt TM, Bautista B, et al. Effector CD4 T-cell transition to memory requires late cognate interactions that induce autocrine IL-2. Nat Commun. 2014;5:5377. doi:10.1038/ncomms6377

60. Surh CD, Sprent J. Homeostasis of naive and memory T cells. Immunity. 2008;29(6):848-862. doi:10.1016/j. immuni.2008.11.002

61. Fazilleau N, Eisenbraun MD, Malherbe L, et al. Lymphoid reservoirs of antigen-specific memory $\mathrm{T}$ helper cells. Nat Immunol. 2007;8(7):753-761. doi:10.1038/ni1472

62. Gasper DJ, Tejera MM, Suresh M. CD4 T-cell memory generation and maintenance. Crit Rev Immunol. 2014;34(2):121-146. doi:10.1615/CritRevImmunol.2014010373

63. Gramaglia I, Jember A, Pippig SD, Weinberg AD, Killeen N, Croft $\mathrm{M}$. The OX40 costimulatory receptor determines the development of CD4 memory by regulating primary clonal expansion. $J \quad$ Immunol. 2000;165(6):3043-3050. doi:10.4049/ jimmunol.165.6.3043

64. Schiott A, Lindstedt M, Johansson-Lindbom B, Roggen E, Borrebaeck CA. CD27- CD4+ memory $\mathrm{T}$ cells define a differentiated memory population at both the functional and transcriptional levels. Immunology. 2004;113(3):363-370. doi:10.1111/j.1365-2567.2004.01974.x

65. Crotty S. T follicular helper cell biology: a decade of discovery and diseases. Immunity. 2019;50(5):1132-1148. doi:10.1016/j. immuni.2019.04.011

66. Zhang B, Liu E, Gertie JA, et al. Divergent T follicular helper cell requirement for $\mathrm{IgA}$ and $\mathrm{IgE}$ production to peanut during allergic sensitization. Sci Immunol. 2020;5(47). doi:10.1126/sciimmunol. aay 2754

67. Noble A, Zhao J. Follicular helper T cells are responsible for IgE responses to Der $\mathrm{p} 1$ following house dust mite sensitization in mice. Clin Exp Allergy. 2016;46(8):1075-1082. doi:10.1111/ cea. 12750

68. Dolence JJ, Kobayashi T, Iijima K, et al. Airway exposure initiates peanut allergy by involving the IL-1 pathway and T follicular helper cells in mice. J Allergy Clin Immunol. 2018;142 (4):1144-1158.

69. Lu KT, Kanno Y, Cannons JL, et al. Functional and epigenetic studies reveal multistep differentiation and plasticity of in vitro-generated and in vivo-derived follicular $\mathrm{T}$ helper cells. Immunity. 2011;35(4):622-632. doi:10.1016/j. immuni.2011.07.015

70. Vogelzang A, McGuire HM, Yu D, Sprent J, Mackay CR, King C. A fundamental role for interleukin-21 in the generation of $\mathrm{T}$ follicular helper cells. Immunity. 2008;29(1):127-137. doi:10.1016/j.immuni.2008.06.001
71. Weber JP, Fuhrmann F, Feist RK, et al. ICOS maintains the $\mathrm{T}$ follicular helper cell phenotype by down-regulating Kruppel-like factor 2. J Exp Med. 2015;212(2):217-233. doi:10.1084/jem.20141432

72. Mahajan S, Cervera A, MacLeod M, et al. The role of ICOS in the development of CD4 T cell help and the reactivation of memory T cells. Eur $J$ Immunol. 2007;37(7):1796-1808. doi:10.1002/eji.200636661

73. Merkenschlager J, Finkin S, Ramos V, et al. Dynamic regulation of TFH selection during the germinal centre reaction. Nature. 2021;591(7850):458-463. doi:10.1038/s41586-021-03187-x

74. Kunzli M, Schreiner D, Pereboom TC, et al. Long-lived $\mathrm{T}$ follicular helper cells retain plasticity and help sustain humoral immunity. Sci Immunol. 2020;5(45):eaay5552. doi:10.1126/sciimmunol.aay5552

75. Alterauge D, Bagnoli JW, Dahlstrom F, et al. Continued Bcl6 expression prevents the transdifferentiation of established $\mathrm{Tfh}$ cells into Th1 cells during acute viral infection. Cell Rep. 2020;33(1):108232. doi:10.1016/j.celrep.2020.108232

76. Alvarez D, Arkinson JL, Sun J, Fattouh R, Walker T, Jordana M. Th2 differentiation in distinct lymph nodes influences the site of mucosal Th2 immune-inflammatory responses. $J$ Immunol. 2007;179(5):3287-3296. doi:10.4049/jimmunol.179.5.3287

77. Ugur M, Schulz O, Menon MB, Krueger A, Pabst O. Resident CD4+ $\mathrm{T}$ cells accumulate in lymphoid organs after prolonged antigen exposure. Nat Commun. 2014;5:4821. doi:10.1038/ ncomms 5821

78. Islam SA, Luster $\mathrm{AD}$. T cell homing to epithelial barriers in allergic disease. Nat Med. 2012;18(5):705-715. doi:10.1038/ nm. 2760

79. Masopust D, Choo D, Vezys V, et al. Dynamic T cell migration program provides resident memory within intestinal epithelium. $J$ Exp Med. 2010;207(3):553-564. doi:10.1084/jem.20090858

80. Hondowicz BD, An D, Schenkel JM, et al. Interleukin-2-dependent allergen-specific tissue-resident memory cells drive asthma. Immunity. 2016;44(1):155-166. doi:10.1016/j. immuni.2015.11.004

81. Bosnjak B, Kazemi S, Altenburger LM, Mokrovic G, Epstein MM. Th2-TRMs maintain life-long allergic memory in experimental asthma in mice. Front Immunol. 2019;10:840. doi:10.3389/fimmu.2019.00840

82. Steinbach K, Vincenti I, Merkler D. Resident-memory T cells in tissue-restricted immune responses: for better or worse? Front Immunol. 2018;9:2827. doi:10.3389/fimmu.2018.02827

83. Carrasco YR, Batista FD. B cells acquire particulate antigen in a macrophage-rich area at the boundary between the follicle and the subcapsular sinus of the lymph node. Immunity. 2007;27(1):160-171.

84. Cyster JG, Allen CDC. B cell responses: cell interaction dynamics and decisions. Cell. 2019;177(3):524-540. doi:10.1016/j.cell.2019.03.016

85. Yao Y, Chen CL, Yu D, Liu Z. Roles of follicular helper and regulatory $\mathrm{T}$ cells in allergic diseases and allergen immunotherapy. Allergy. 2021;76(2):456-470. doi:10.1111/all.14639

86. Taylor JJ, Pape KA, Jenkins MK. A germinal center-independent pathway generates unswitched memory B cells early in the primary response. J Exp Med. 2012;209(3):597-606. doi:10.1084/ jem. 20111696

87. Roco JA, Mesin L, Binder SC, et al. Class-switch recombination occurs infrequently in germinal centers. Immunity. 2019;51 (2):337-350 e337. doi:10.1016/j.immuni.2019.07.001

88. Allie SR, Bradley JE, Mudunuru U, et al. The establishment of resident memory $\mathrm{B}$ cells in the lung requires local antigen encounter. Nat Immunol. 2019;20(1):97-108. doi:10.1038/ s41590-018-0260-6 
89. Yang Z, Robinson MJ, Allen CD. Regulatory constraints in the generation and differentiation of IgE-expressing B cells. Curr Opin Immunol. 2014;28:64-70. doi:10.1016/j.coi.2014.02.001

90. Finney J, Yeh C-H, Kelsoe G, Kuraoka M. Germinal center responses to complex antigens. Immunol Rev. 2018;284 (1):42-50. doi:10.1111/imr.12661

91. Zuccarino-Catania GV, Sadanand S, Weisel FJ, et al. CD80 and PD-L2 define functionally distinct memory B cell subsets that are independent of antibody isotype. Nat Immunol. 2014;15 (7):631-637. doi:10.1038/ni.2914

92. Di Niro R, Lee SJ, Vander Heiden JA, et al. Salmonella infection drives promiscuous $\mathrm{b}$ cell activation followed by extrafollicular affinity maturation. Immunity. 2015;43(1):120-131. doi:10.1016/j. immuni.2015.06.013

93. Yang Z, Robinson MJ, Chen X, et al. Regulation of B cell fate by chronic activity of the $\mathrm{IgE} B$ cell receptor. Elife. 2016;5. doi:10.7554/eLife. 21238

94. Haniuda K, Fukao S, Kodama T, Hasegawa H, Kitamura D. Autonomous membrane IgE signaling prevents IgE-memory formation. Nat Immunol. 2016;17(9):1109-1117. doi:10.1038/ ni. 3508

95. Laffleur B, Debeaupuis O, Dalloul Z, Cogne M. B cell intrinsic mechanisms constraining IgE memory. Front Immunol. 2017;8 (1277):1277. doi:10.3389/fimmu.2017.01277

96. Blazquez AB, Berin MC. Gastrointestinal dendritic cells promote Th2 skewing via OX40L. J Immunol. 2008;180(7):4441-4450. doi:10.4049/jimmunol.180.7.4441

97. Adler LN, Jiang W, Bhamidipati K, et al. The other function: class II-restricted antigen presentation by B cells. Front Immunol. 2017;8:319. doi:10.3389/fimmu.2017.00319

98. Moutsoglou DM, Dreskin SC. B cells establish, but do not maintain, long-lived murine anti-peanut $\operatorname{IgE}(\mathrm{a})$. Clin Exp Allergy. 2016;46(4):640-653. doi:10.1111/cea.12715

99. Harris DP, Goodrich S, Mohrs K, Mohrs M, Lund FE. Cutting edge: the development of IL-4-producing B cells (B effector 2 cells) is controlled by IL-4, IL-4 receptor alpha, and Th2 cells. $J \quad$ Immunol. 2005;175(11):7103-7107. doi:10.4049/ jimmunol.175.11.7103

100. Katona IM, Urban JF Jr, Kang SS, Paul WE, Finkelman FD. IL-4 requirements for the generation of secondary in vivo $\operatorname{IgE}$ responses. J Immunol. 1991;146(12):4215-4221.

101. Finkelman FD, Katona IM, Urban JF Jr, et al. IL-4 is required to generate and sustain in vivo IgE responses. J Immunol. 1988;141 (7):2335-2341.

102. King IL, Mohrs M. IL-4-producing CD4+ T cells in reactive lymph nodes during helminth infection are $\mathrm{T}$ follicular helper cells. $J$ Exp Med. 2009;206(5):1001-1007. doi:10.1084/ jem.20090313

103. Liang HE, Reinhardt RL, Bando JK, Sullivan BM, Ho IC, Locksley RM. Divergent expression patterns of IL-4 and IL-13 define unique functions in allergic immunity. Nat Immunol. 2011;13(1):58-66. doi:10.1038/ni.2182

104. McHeyzer-Williams M, Okitsu S, Wang N, McHeyzer-Williams L. Molecular programming of B cell memory. Nat Rev Immunol. 2011;12(1):24-34. doi:10.1038/nri3128

105. Etzioni A, Ochs HD. The hyper IgM syndrome-an evolving story. Pediatr Res. 2004;56(4):519-525. doi:10.1203/01. PDR.0000139318.65842.4A

106. Dong C, Juedes AE, Temann UA, et al. ICOS co-stimulatory receptor is essential for T-cell activation and function. Nature. 2001;409(6816):97-101. doi:10.1038/35051100

107. Latham LE, Wikenheiser DJ, Stumhofer JS. ICOS signaling promotes a secondary humoral response after re-challenge with Plasmodium chabaudi chabaudi AS. PLoS Pathog. 2020;16(4): e1008527. doi:10.1371/journal.ppat.1008527
108. Salek-Ardakani S, Song J, Halteman BS, et al. OX40 (CD134) controls memory $\mathrm{T}$ helper 2 cells that drive lung inflammation. J Exp Med. 2003;198(2):315-324. doi:10.1084/jem.20021937

109. Takatsuka S, Yamada H, Haniuda K, et al. IL-9 receptor signaling in memory B cells regulates humoral recall responses. Nat Immunol. 2018;19(9):1025-1034. doi:10.1038/s41590-018-01770

110. Blazquez AB, Knight $\mathrm{AK}$, Getachew $\mathrm{H}$, et al. A functional role for CCR6 on proallergic $\mathrm{T}$ cells in the gastrointestinal tract. Gastroenterology. 2010;138(1):275-284 e271-274. doi:10.1053/ j.gastro.2009.09.016

111. Aguilera-Lizarraga J, Florens MV, Viola MF, et al. Local immune response to food antigens drives meal-induced abdominal pain. Nature. $\quad 2021 ; 590(7844): 151-156 . \quad$ doi:10.1038/s41586-02003118-2

112. Moran I, Nguyen A, Khoo WH, et al. Memory B cells are reactivated in subcapsular proliferative foci of lymph nodes. Nat Commun. 2018;9(1):3372. doi:10.1038/s41467-018-05772-7

113. Palm AE, Henry C. Remembrance of things past: long-term B cell memory after infection and vaccination. Front Immunol. 2019;10(1787):1787. doi:10.3389/fimmu.2019.01787

114. Syed A, Garcia MA, Lyu SC, et al. Peanut oral immunotherapy results in increased antigen-induced regulatory $\mathrm{T}$-cell function and hypomethylation of forkhead box protein 3 (FOXP3). J Allergy Clin Immunol. 2014;133(2):500-510. doi:10.1016/j. jaci.2013.12.1037

115. Karlsson MR, Rugtveit J, Brandtzaeg P. Allergen-responsive CD4 $+\mathrm{CD} 25+$ regulatory $\mathrm{T}$ cells in children who have outgrown cow's milk allergy. J Exp Med. 2004;199(12):1679-1688. doi:10.1084/ jem.20032121

116. Sayin I, Radtke AJ, Vella LA, et al. Spatial distribution and function of $\mathrm{T}$ follicular regulatory cells in human lymph nodes. $J$ Exp Med. 2018;215(6):1531-1542. doi:10.1084/jem.20171940

117. Clement RL, Daccache J, Mohammed MT, et al. Follicular regulatory $\mathrm{T}$ cells control humoral and allergic immunity by restraining early B cell responses. Nat Immunol. 2019;20(10):1360-1371. doi:10.1038/s41590-019-0472-4

118. Xie MM, Chen Q, Liu H, et al. T follicular regulatory cells and IL-10 promote food antigen-specific IgE. J Clin Invest. 2020;130 (7):3820-3832. doi:10.1172/JCI132249

119. Canete PF, Sweet RA, Gonzalez-Figueroa P, et al. Regulatory roles of IL-10-producing human follicular T cells. J Exp Med. 2019;216(8):1843-1856. doi:10.1084/jem.20190493

120. Yang Z, Wu CM, Targ S, Allen CDC. IL-21 is a broad negative regulator of IgE class switch recombination in mouse and human B cells. J Exp Med. 2020;217(5). doi:10.1084/jem.20190472

121. Rosser EC, Mauri C. Regulatory B cells: origin, phenotype, and function. Immunity. 2015;42(4):607-612. doi:10.1016/j. immuni.2015.04.005

122. Ma S, Satitsuksanoa P, Jansen K, Cevhertas L, van de Veen W, Akdis M. B regulatory cells in allergy. Immunol Rev. 2020. doi:10.1111/imr.12937

123. Jansen K, Cevhertas L, Ma S, Satitsuksanoa P, Akdis M, van de Veen W. Regulatory B cells, A to Z. Allergy. 2021. doi:10.1111/ all.14763

124. Jimenez-Saiz R, Patil SU. The multifaceted B cell response in allergen immunotherapy. Curr Allergy Asthma Rep. 2018;18 (12):66. doi:10.1007/s11882-018-0819-1

125. Boonpiyathad T, Meyer N, Moniuszko M, et al. High-dose bee venom exposure induces similar tolerogenic B-cell responses in allergic patients and healthy beekeepers. Allergy. 2017;72 (3):407-415. doi:10.1111/all.12966

126. Boonpiyathad T, Tantilipikorn P, Ruxrungtham K, et al. IL-10producing innate lymphoid cells increased in patients with house dust mite allergic rhinitis following immunotherapy. $J$ Allergy Clin Immunol. 2020. 
127. Zissler UM, Jakwerth CA, Guerth FM, et al. Early IL-10 producing B-cells and coinciding $\operatorname{Th} / \operatorname{Tr} 17$ shifts during three year grass-pollen AIT. EBioMedicine. 2018;36:475-488. doi:10.1016/ j.ebiom.2018.09.016
128. Armingol E, Officer A, Harismendy O, Lewis NE. Deciphering cell-cell interactions and communication from gene expression. Nat Rev Genet. 2021;22(2):71-88. doi:10.1038/s41576-02000292-x

\section{Publish your work in this journal}

ImmunoTargets and Therapy is an international, peer-reviewed open access journal focusing on the immunological basis of diseases, potential targets for immune based therapy and treatment protocols employed to improve patient management. Basic immunology and physiology of the immune system in health, and disease will be also covered. In addition, the journal will focus on the impact of management programs and new therapeutic agents and protocols on patient perspectives such as quality of life, adherence and satisfaction. The manuscript management system is completely online and includes a very quick and fair peer-review system, which is all easy to use. Visit http://www.dovepress.com/testimonials.php to read real quotes from published authors. 